\title{
Safety and tolerability of moxifloxacin in the treatment of respiratory tract infections: a post-marketing surveillance conducted in Indonesia
}

\author{
Arini Setiawati ${ }^{*}$, Iwan Darmansjah ${ }^{*}$, Hadiarto Mangunnegoro ${ }^{* *}$
}

\begin{abstract}
Abstrak
Tablet moxifloxacin $400 \mathrm{mg}$ telah dipasarkan di Indonesia untuk beberapa indikasi, yaitu bronkitis kronik eksaserbasi akut, pneumonia didapat di komunitas, dan sinusitis bakterial akut. Untuk menilai keamanan dan tolerabilitas moxifloxacin, dilakukan survei pasca pemasaran pada tahun 2001 yang melibatkan 589 dokter. Selain itu, dinilai pula efikasi kliniknya, baik oleh dokter maupun pasien, dengan menggunakan total skor 6 gejala yang berskala 0-12. Seluruhnya, diperoleh 1715 pasien dengan sinusitis akut, pneumonia didapat di komunitas, bronkitis kronik eksaserbasi akut dan infeksi lainnya yang diobati dengan moxifloxacin oral 400 mg sekali sehari. Sebanyak 151 (8,8\%) pasien melaporkan efek samping dan 5 (0.29\%) pasien mengalami efek samping serius, yang dianggap berhubungan dengan terapi moxifloxacin. Efek samping tersering adalah mual (4.96\%), pusing (1.52\%), muntah $(0.64 \%)$, sakit kepala $(0,47 \%)$, dan lemah $(0,47 \%)$. Duapuluh tiga $(1,34 \%)$ pasien menghentikan terapi akibat efek samping. Toleransi terhadap terapi dinilai sangat baik oleh 647 (37,7\%) dan baik oleh 919 (53,6\%) pasien. Berdasarkan penilaian klinis oleh dokter, $57,7 \%$ pasien dinyatakan sembuh dan $39.9 \%$ dinyatakan membaik di akhir terapi. Rerata skor gejala total, sebagaimana dinilai oleh pasien, turun dari 6,43 pada hari pertama menjadi 2,76 pada hari ketiga. Secara umum, 95.3\% pasien merasa lebih baik setelah mendapat moxifloxacin dan 97,6\% pasien memberikan kesan baik terhadap terapi moxifloxacin. Sebagai kesimpulan, survei pasca pemasaran ini menunjukkan bahwa pengobatan infeksi saluran napas oleh bakteri, terutama bronkitis, pneumonia komunitas dan sinusitis, dengan moxifloxacin $400 \mathrm{mg}$ sekali sehari aman dan dapat ditoleransi dengan baik, dan juga bahwa moxifloxacin sangat efektif untuk pengobatan infeksi ini dengan perbaikan gejala yang cepat. (Med J Indones 2005; 14: 11-19)
\end{abstract}

\begin{abstract}
Moxifloxacin $400 \mathrm{mg}$ tablet has been marketed in Indonesia for several indications, i.e. acute exacerbation of chronic bronchitis $(A E C B)$, community-acquired pneumonia $(C A P)$, and acute bacterial sinusitis $(A B S)$. To assess the safety and tolerability of moxifloxacin, a post-marketing surveillance study was conducted in the year 2001 involving 589 physicians. Clinical efficacy was also evaluated, both by physicians and patients, using a 6-symptom total score, which was scaled 0-12. A total of 1715 patients with acute sinusitis, CAP, AECB, and other infections were treated with oral moxifloxacin $400 \mathrm{mg}$ once daily. There were 151 (8.8\%) patients with adverse events (AES) and $5(0.29 \%)$ patients with serious adverse events (SAEs) that were considered related to moxifloxacin treatment. The most common adverse reactions were nausea (4.96\%), dizziness (1.52\%), vomiting (0.64\%), headache (0.47\%), and weakness $(0.47 \%)$. Twenty three (1.34\%) patients discontinued treatment due to adverse events. Tolerance to treatment was rated very good and good by 647 (37.7\%) and 919 (53.6\%) of patients, respectively. Based on physicians' clinical assessment, 57.7\% of patients were cured and $39.9 \%$ were improved at the end of treatment. Mean total symptom score, as assessed by the patients, decreased from 6.43 on day-1 to 2.76 on day-3. Totally, 95.3\% of patients felt better after receiving moxifloxacin and $97.6 \%$ of patients had good impression on moxifloxacin treatment. In conclusion, treatment of respiratory tract infections, mainly $A E C B$, CAP and ABS, with moxifloxacin $400 \mathrm{mg}$ once daily in this post-marketing surveillance was shown to be safe and well tolerated. Moxifloxacin was also shown to be highly effective in the treatment of these infections with rapid improvement of symptoms. (Med J Indones 2005; 14: 11-19)
\end{abstract}

Keywords : post-marketing surveillance, PMS, moxifloxacin, respiratory tract infections

The respiratory system is prone to infection at many sites from the nose to the lungs. Respiratory tract

\footnotetext{
*PUKO - Clinical Trial Center, ${ }^{* *}$ Department of Pulmonology Persahabatan Hospital, Faculty of Medicine, University of Indonesia, Jakarta, Indonesia
}

infections (RTIs) remain the principal causes of death throughout the world as these infections can be serious and potentially life threatening. The degree and duration of symptoms can have a major impact on patients' quality of life and can present a major economic burden. ${ }^{1}$ On the other hand, the increasing bacterial resistance to antibiotics is a significant challenge to be overcome. 
A new fluoroquinolone, moxifloxacin, has been proven to have many advantages in the management of RTIs. It has high activity against the key RTI pathogens. In vitro and in vivo animal studies have shown that moxifloxacin has a broad but appropriate spectrum of antimicrobial activity against Gram-positive, Gramnegative and atypical micro-organisms for the empirical treatment of RTIs. ${ }^{2}$

Moxifloxacin $400 \mathrm{mg}$ tablet has been approved by the Indonesian National Agency of Drug and Food Control (Badan Pengawas Obat dan Makanan $[\mathrm{BPOM}]$ ) and officially labelled for acute exacerbation of chronic bronchitis (AECB), community-acquired pneumonia (CAP), and acute bacterial sinusitis (ABS). These RTIs are the leading causes of illness in Indonesia with significant morbidity, which result in a considerable loss of productivity and quality of life of the patients. Infections in the very young, in elderly people and in patients with underlying disease and/ or immunocompromized may also be life threatening. Therefore, early detection and rapid cure is of vital importance from a prognostic standpoint as well as from a quality of life viewpoint.

The primary objective of this post-marketing study was to observe the safety and tolerability of moxifloxacin $400 \mathrm{mg}$ once daily in the treatment of RTIs. An additional objective was to confirm the efficacy and rapidity of action in daily clinical practice.

\section{PATIENTS AND METHODS}

\section{Patients}

This post-marketing surveillance was conducted at private clinics throughout Indonesia between 24 March and 6 September 2001. A total of 1717 patients were collected in this post-marketing study with the diagnosis of acute sinusitis, acute exacerbation of chronic bronchitis, community-acquired pneumonia, and other indications, which were left to the discretion of the attending physicians. In total, 589 physicians participated in the study and 1717 case report forms were returned. One thousand seven hundreds and fifteen patients were included for safety analysis and 1714 patients were analysed for efficacy.

\section{Clinical Assessment}

Patients were clinically assessed by the attending physicians, which included demographic data, diagnosis, concomitant disease, prior antibiotic, concomitant treatment, moxifloxacin treatment, and outcome. These data were recorded in the Case Report Form (CRF). Clinical efficacy was assessed based on 6 major signs \& symptoms : fever, cough, dyspnoea, chest pain, purulent sputum, and lethargy. Each symptom was scored 0 to 2, resulting in a total symptom score (TSS) of 0 to 12. Any other symptoms or signs were also recorded in the CRFs. Based on the physicians' global assessment, patients were declared cured, improved, no response, or unevaluable.

In addition to physician assessment, subjective evaluation was also made by the patients. Patients had to rate the above 6 major symptoms on the first day, the third day and the last day of moxifloxacin treatment. Any other symptoms or signs were also reported. In order to evaluate the rapidity of moxifloxacin action, the number of days for improvement and cure since the first dose of moxifloxacin were documented.

All CRFs from individual investigators were returned to the Clinical Trial Center, Faculty of Medicine, University of Indonesia, Jakarta for analysis.

\section{Adverse Events}

All adverse events during the study period were recorded irrespective of causal relationship with the investigated drug. Any adverse event was described in detail, including the signs and symptoms, onset, nature and duration. Investigators also recorded the actions taken, the outcome, and the possible relationship to moxifloxacin therapy.

A serious adverse event (SAE) was defined as one resulting in death, a life-threatening event, requiring inpatient hospitalization or prolongation of existing hospitalization, persistent or significant disability/ incapacity, or any other $\mathrm{AE}$ which was considered serious by the respective physician. The physicians were requested to report any SAEs occurring during the study period within 24 hours by fax, telephone or e-mail to PT Bayer Indonesia.

\section{Data Management and Statistical Analysis}

Prior to data entry and analysis, the CRFs were checked for completeness and plausibility. Any missing or implausible data on the CRFs were communicated with the respective physician by telephone or mail to be resolved. 
Descriptive statistics were performed to analyze the adverse events and the clinical efficacy. Kaplan-Meier curves were developed for improvement and cure. All statistical analyses were done using statistical software system SPSS for Windows version 10.0.

\section{RESULTS}

\section{Demographic}

A total of 1717 patients were collected during the study period. Two patients were excluded from safety analysis because post-treatment data were absent. Another patient was also excluded from efficacy analysis because the diagnosis was gonorrhea. Of the 1715 patients analyzed for safety, 1018 (59.4\%) were males. Median age was 43 years within the range of 2 to 95 years. Diagnosis of patients consisted of 771 (45.0\%) AECBs, 394 (23.0\%) acute sinusitis cases, 344 (20.1\%) CAPs, and $205(12.0 \%)$ miscellaneous diseases. Disease severity was categorized as mild (7.1\%), moderate $(70.7 \%)$, and severe $(22.3 \%)$. Most off-label indications were mainly other upper and lower respiratory tract infections (Table 1).

Table 1. Patients' characteristics

\begin{tabular}{llrr}
\hline Sex & Male & 1018 & $59.4 \%$ \\
& Female & 697 & $40.6 \%$ \\
Age & Mean: 44.4 years & & \\
Diagnosis & Median: 43 years & & \\
& Acute sinusitis & 394 & $23.0 \%$ \\
& AECB & 771 & $45.0 \%$ \\
& CAP & 344 & $20.1 \%$ \\
& Miscellaneous: & & \\
& - Upper RTIs & 86 & $5 \%$ \\
& - Lower RTIs & 107 & $6.2 \%$ \\
& - Other infections & 12 & $0.7 \%$ \\
Disease severity & Mild & 121 & $7.1 \%$ \\
& Moderate & 1211 & $70.7 \%$ \\
& Severe & 382 & $22.3 \%$ \\
\hline
\end{tabular}

\section{Moxifloxacin Treatment}

The majority of patients were treated for 5-7 days. The mean duration of treatment was 6.5 days, ranged from 1 to 20 days. The dosage of moxifloxacin was $400 \mathrm{mg}$ daily orally for almost all patients $(99.82 \%)$. Only 2 patients ( 13 and 16 years old) received $200 \mathrm{mg}$ and 1 patient (2 years old) received $60 \mathrm{mg}$ daily. Almost one-fourth of patients $(23.1 \%)$ were smokers and $10.4 \%$ were ex-smokers.

\section{Prior and Concomitant Treatment}

About half of the patients $(54.6 \%)$ have received antibiotics within 7 days prior to moxifloxacin administration. Most of them were penicillins (51.6\%), followed by macrolides (15.0\%), quinolones (14.5\%), cephalosporins $(11.2 \%)$, and others $(7.7 \%)$. During moxifloxacin treatment, $96.3 \%$ of patients did not receive other concomitant antibiotics.

As a post-marketing study, other medications were not controlled and were left to the physicians' judgment as he/ she would prescribe in their routine practices. These include the use of antipyretic drug (paracetamol), firstand second-generation antihistamines, nasal decongestant, bronchodilators, antitussives, and expectorants.

\section{Safety and Tolerability}

A total of 178 patients (10.38\% of 1715) reported 292 adverse events (AEs), of which 232 AEs (79.4\%) occurring in 151 patients $(8.8 \%)$ were considered to have possible or probable relationship with moxifloxacin therapy (Figure 1). Seven patients $(0.41 \%)$ experienced 14 serious adverse events (SAEs), including 2 deaths. Seven SAEs, occurring in 5 patients $(0.29 \%)$, were considered to be possibly or probably related to treatment (Table 3 ). There were 2 deaths, both deaths were considered unrelated to moxifloxacin treatment by the investigators. One death was caused by anasarca, pulmonary edema and hypoglycemia. The other death was due to acute heart failure, pulmonary edema and dyspnea.

Table 2 shows the list of 278 nonserious AEs occurring in 171 patients $(9.97 \%$ of 1715 ), of which 225 AEs reported by 146 patients $(8.51 \%)$ were considered to be possibly or probably related to treatment. The most frequently reported adverse effects or adverse

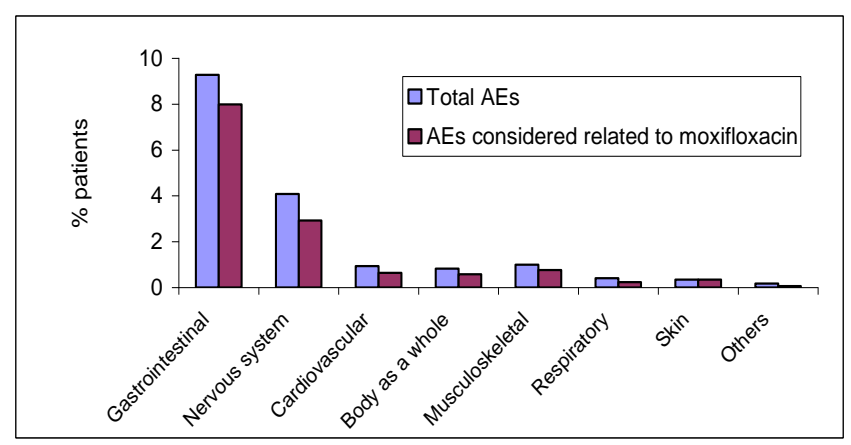

Figure 1. Total AEs and AEs considered related to moxifloxacin 
reactions (adverse events considered related to treatment), both serious and nonserious, involved the gastrointestinal system $(137 / 1715$ patients $=7.99 \%)$ and the nervous system $(50=2.92 \%)$. The most common individual adverse reactions were nausea $(85$ $=4.96 \%)$, dizziness $(26=1.52 \%)$, vomiting $(11=0.64 \%)$, headache $(8=0.47 \%)$, and weakness $(8=0.47 \%)$.
Twenty-three $(1.34 \%)$ patients discontinued treatment due to AEs. Table 4 lists 38 AEs causing discontinuation, of which 37 AEs were considered related to moxifloxacin. Tolerance to moxifloxacin treatment was rated very good in $647(37.7 \%)$ patients, good in $919(53.6 \%)$ patients, adequate in $100(5.8 \%)$ patients, not adequate in $33(1.9 \%)$ patients, and unevaluable in $16(0.9 \%)$ patients.

Table 2. List of nonserious AEs, total and those considered related to moxifloxacin treatment

\begin{tabular}{|c|c|c|}
\hline & $\begin{array}{c}\text { Total AEs } \\
\text { No. (\% incidence) }\end{array}$ & $\begin{array}{l}\text { AEs related to moxifloxacin } \\
\text { No. (\% incidence) }\end{array}$ \\
\hline Gastrointestinal & $153(8.92)$ & $131(7.64)$ \\
\hline$\bullet \quad$ Nausea & $91(5.31)$ & $82(4.78)$ \\
\hline - Vomiting & $12(0.70)$ & $9(0.52)$ \\
\hline - Dyspepsia & $9(0.52)$ & $7(0.41)$ \\
\hline - Diarrhoea & $7(0.41)$ & $6(0.35)$ \\
\hline - Abdominal pain & $7(0.41)$ & $5(0.29)$ \\
\hline - $\quad$ Epigastric pain & $6(0.35)$ & $5(0.29)$ \\
\hline - $\quad$ Dry mouth & $6(0.35)$ & $4(0.23)$ \\
\hline - Anorexia & $3(0.17)$ & $1(0.06)$ \\
\hline - Bitter taste & $2(0.12)$ & $2(0.12)$ \\
\hline - $\quad$ Meteorism & $1(0.06)$ & $1(0.06)$ \\
\hline - Abdominal colic & $1(0.06)$ & $1(0.06)$ \\
\hline - $\quad$ Gastric colic & $1(0.06)$ & $1(0.06)$ \\
\hline - $\quad$ Distended stomach & $1(0.06)$ & $1(0.06)$ \\
\hline - $\quad$ Swallowing difficulty & $1(0.06)$ & $1(0.06)$ \\
\hline - Dry lips & $1(0.06)$ & $1(0.06)$ \\
\hline - Oral pain & $1(0.06)$ & $1(0.06)$ \\
\hline - Metallic taste & $1(0.06)$ & $1(0.06)$ \\
\hline - Constipation & $1(0.06)$ & $1(0.06)$ \\
\hline - $\quad$ More frequent defecation & $1(0.06)$ & $1(0.06)$ \\
\hline Nervous system (central, peripheral, autonomic) & $69(4.02)$ & $49(2.86)$ \\
\hline$\bullet \quad$ Dizziness & $37(2.16)$ & $26(1.52)$ \\
\hline - Headache & $9(0.52)$ & $8(0.47)$ \\
\hline - Insomnia & $6(0.35)$ & $4(0.23)$ \\
\hline - $\quad$ Sweating & $6(0.35)$ & $3(0.17)$ \\
\hline - $\quad$ Tremor & $4(0.23)$ & $2(0.12)$ \\
\hline - $\quad$ Vertigo & $3(0.17)$ & $3(0.17)$ \\
\hline - $\quad$ Giddiness & $2(0.12)$ & $2(0.12)$ \\
\hline - $\quad$ Lightheadedness & $1(0.06)$ & $1(0.06)$ \\
\hline - Drowsiness & $1(0.06)$ & - \\
\hline Cardiovascular system & $15(0.87)$ & $11(0.64)$ \\
\hline$\bullet \quad$ Palpitation & $9(0.52)$ & $7(0.41)$ \\
\hline - $\quad$ Chest pain & $2(0.12)$ & $1(0.06)$ \\
\hline - $\quad$ Tachycardia & $1(0.06)$ & $1(0.06)$ \\
\hline - $\quad$ Bradycardia & $1(0.06)$ & $1(0.06)$ \\
\hline - $\quad$ Chest burning & $1(0.06)$ & $1(0.06)$ \\
\hline - $\quad$ Syncope & $1(0.06)$ & $?$ \\
\hline Body as a Whole & $12(0.70)$ & $10(0.58)$ \\
\hline$\bullet \quad$ Weakness & $8(0.47)$ & $8(0.47)$ \\
\hline - $\quad$ Malaise & $3(0.17)$ & $2(0.12)$ \\
\hline - $\quad$ Fever & $1(0.06)$ & - \\
\hline Musculoskeletal system & $17(0.99)$ & $13(0.76)$ \\
\hline • Myalgia & $7(0.41)$ & $4(0.23)$ \\
\hline - $\quad$ Arthralgia & $5(0.29)$ & $4(0.23)$ \\
\hline - Swollen joint & $1(0.06)$ & $1(0.06)$ \\
\hline - Back pain & $1(0.06)$ & $1(0.06)$ \\
\hline - $\quad$ Neck pain & $1(0.06)$ & $1(0.06)$ \\
\hline - Body ache & $1(0.06)$ & $1(0.06)$ \\
\hline - Weak and painful leg & $1(0.06)$ & $1(0.06)$ \\
\hline Respiratory & $4(0.23)$ & $4(0.23)$ \\
\hline - Dyspnea & $2(0.12)$ & $2(0.12)$ \\
\hline - Nose pain & $1(0.06)$ & $1(0.06)$ \\
\hline - Viscous sputum & $1(0.06)$ & $1(0.06)$ \\
\hline Skin & $6(0.35)$ & $6(0.35)$ \\
\hline - $\quad$ Urticaria & $2(0.12)$ & $2(0.12)$ \\
\hline - $\quad$ Pruritus & $2(0.12)$ & $2(0.12)$ \\
\hline - $\quad$ Erythema & $2(0.12)$ & $2(0.12)$ \\
\hline Special senses & $1(0.06)$ & $1(0.06)$ \\
\hline - $\quad$ Blurred vision & $1(0.06)$ & $1(0.06)$ \\
\hline Renal & $1(0.06)$ & - \\
\hline - $\quad$ Polyuria & $1(0.06)$ & - \\
\hline Total & $278(16.21)$ & $225(13.12)$ \\
\hline
\end{tabular}


Table 3. List of SAEs, total and those considered related to moxifloxacin treatment

\begin{tabular}{lcc}
\hline & $\begin{array}{c}\text { Total SAEs } \\
\text { No (\% incidence) }\end{array}$ & $\begin{array}{c}\text { SAEs related to } \\
\text { moxifloxacin } \\
\text { No (\% incidence) }\end{array}$ \\
\hline Bad nausea & $1(0.06)$ & $1(0.06)$ \\
Nausea & $2(0.12)$ & $2(0.12)$ \\
Vomiting & $2(0.12)$ & $2(0.12)$ \\
Vertigo & $1(0.06)$ & $1(0.06)$ \\
Liver dysfunction & $1(0.06)$ & $1(0.06)$ \\
High fever & $1(0.06)$ & - \\
Anasarca & $1(0.06)$ & - \\
Pulmonary edema & $2(0.12)$ & - \\
Acute heart failure & $1(0.06)$ & - \\
Dyspnea & $1(0.06)$ & - \\
Hypoglycemia & $1(0.06)$ & - \\
\hline Total & $14(0.82)$ & $7(0.41)$ \\
\hline
\end{tabular}

Table 4. Causes of treatment discontinuation

\begin{tabular}{lcc}
\hline & $\begin{array}{c}\text { AEs } \\
\text { No (\% incidence) }\end{array}$ & $\begin{array}{c}\text { AEs related to } \\
\text { moxifloxacin } \\
\text { No. (\% incidence) }\end{array}$ \\
\hline Nausea & $7(0.41)$ & $7(0.41)$ \\
Weakness & $3(0.17)$ & $3(0.17)$ \\
Dizziness & $3(0.17)$ & $3(0.17)$ \\
Palpitation & $3(0.17)$ & $3(0.17)$ \\
Headache & $2(0.12)$ & $2(0.12)$ \\
Abdominal pain & $2(0.12)$ & $2(0.12)$ \\
Epigastric pain & $2(0.12)$ & $2(0.12)$ \\
Dyspnea & $2(0.12)$ & $2(0.12)$ \\
Vomiting & $1(0.06)$ & $1(0.06)$ \\
Gastric colic & $1(0.06)$ & $1(0.06)$ \\
Swollen joint & $1(0.06)$ & $1(0.06)$ \\
Arthralgia & $1(0.06)$ & $1(0.06)$ \\
Myalgia & $1(0.06)$ & $1(0.06)$ \\
Insomnia & $1(0.06)$ & $1(0.06)$ \\
Tachycardia & $1(0.06)$ & $1(0.06)$ \\
Bradycardia & $1(0.06)$ & $1(0.06)$ \\
Syncope & $1(0.06)$ & $?$ \\
Sweating & $1(0.06)$ & $1(0.06)$ \\
Tremor & $1(0.06)$ & $1(0.06)$ \\
Erythema & $1(0.06)$ & $1(0.06)$ \\
Neck pain & $1(0.06)$ & $1(0.06)$ \\
Dry mouth & $1(0.06)$ & $1(0.06)$ \\
\hline Total & $38(2.22)$ & $37(2.16)$ \\
\hline
\end{tabular}

\section{Efficacy and duration of treatment}

From 1714 patients analysed for efficacy, 1181 had 6 symptoms scored by both the physician and the patient. The other 533 patients had only 4 symptoms scored by both the physician and the patient: fever, cough, dyspnea, and purulent secretion, making a total symptom score of 8 .
Assessment of efficacy by physicians revealed that $1675(97.7 \%)$ patients cured and improved. There were $17(1.0 \%)$ patients who failed to respond and 22 $(1.3 \%)$ cases were unevaluable. Efficacy of moxifloxacin in treating various diagnoses is given in Table 5.

The mean duration of moxifloxacin treatment was 6.5 days. The majority of patients received moxifloxacin for 4-7 days (81.9\%); longer treatment (8-10 days) was given to $15.9 \%$ of patients. The longer treatments were mainly in patients with CAP (36.3\% out of 344 patients). There were a small proportion of patients $(0.9 \%)$ who needed prolonged treatment of more than 10 days.

The results below and the discussion that followed were based on the analysis of 1181 patients with all 6 symptoms scored by physicians and patients (a total symptom score of 12). As evaluated by physicians, the mean total symptom score (TSS) before treatment was 6.68 and most patients scored between 4-10 (933/1181 patients or $79.0 \%)$. After treatment, the mean TSS was reduced to 1.50 , with 463 out of 1181 (39.2\%) patients reported $100 \%$ cured, which means that no symptoms remained (score $=0$ ). The TSS before and after treatment and the relative changes (\% improvement) in each diagnosis were given in Table 6.

As evaluated by patients, the mean TSS was decreased from 6.43 on day- 1 to 2.76 on day-3, and 0.96 on the last day of treatment (Table 7). On day-3, 92.9\% of acute sinusitis patients had a TSS $\leq 3$; $89.3 \%$ of AECB patients had a TSS $\leq 5 ; 90.9 \%$ of CAP patients had a TSS $\leq 6$, and $80.0 \%$ of patients with miscellaneous diagnoses had a TSS $\leq 4$.

The time interval until cure or improvement was evaluated by patients. Cure was achieved mostly after 4 to 7 days treatment with moxifloxacin, and 10 days treatment cured $96.5 \%$ of all patients (Table 8). Improvement was achieved even faster, the majority of patients improved after 3 days treatment with moxifloxacin (Figure 2).

Overall, 1634 (95.3\%) patients felt better after taking moxifloxacin, of which, 1615 (98.8\%) patients reported this feeling after consuming 1-3 tablets. Most patients $(97.6 \%)$ had good impression on moxifloxacin treatment (Table 9). 
Table 5. Efficacy of treatment in each diagnosis (evaluated by physicians in total 1714 patients)

\begin{tabular}{lccccc}
\hline Response & Acute Sinusitis & AECB & CAP & Miscell. & Overall \\
& $\mathrm{n}(\%)$ & $\mathrm{n}(\%)$ & $\mathrm{n}(\%)$ & $\mathrm{n}(\%)$ & $\mathrm{N}(\%)$ \\
\hline Cured & $243(61.7)$ & $419(54.3)$ & $212(61.6)$ & $116(56.6)$ & $990(57.7)$ \\
Improved & $144(36.5)$ & $340(44.1)$ & $123(35.8)$ & $78(38.0)$ & $685(39.9)$ \\
No response & $3(0.8)$ & $4(0.5)$ & $4(1.2)$ & $6(2.9)$ & $17(1.0)$ \\
Unevaluable & $4(1.0)$ & $8(1.0)$ & $5(1.5)$ & $5(2.4)$ & $22(1.3)$ \\
\hline Total & $394(100.0)$ & $771(100.0)$ & $344(100.0)$ & $205(100.0)$ & $1714(100.0)$ \\
\hline
\end{tabular}

Table 6. Symptom score improvement in each diagnosis (evaluated by physicians in 1181 patients with TSS = 0-12)

\begin{tabular}{lccccc}
\hline & Acute Sinusitis & AECB & CAP & Miscell. & Overall \\
\hline No. of patients & 270 & 554 & 232 & 125 & 1181 \\
Initial mean score & 4.29 & 7.21 & 8.44 & 6.20 & 6.68 \\
After treatment score & 0.73 & 1.60 & 2.01 & 1.76 & 1.50 \\
\hline \% Improvement & \multicolumn{6}{c}{ No. of patients (\% of total patients) } \\
\hline 100.0 & $155(57.4)$ & $186(33.6)$ & $72(31.0)$ & $50(40.0)$ & $463(39.2)$ \\
$75.0-99.0$ & $48(17.8)$ & $167(30.1)$ & $74(31.9)$ & $23(18.4)$ & $312(26.4)$ \\
$50.0-74.9$ & $46(17.0)$ & $163(29.4)$ & $64(27.6)$ & $33(26.4)$ & $306(25.9)$ \\
$25.0-49.9$ & $11(4.1)$ & $33(6.0)$ & $16(6.9)$ & $10(8.0)$ & $70(5.9)$ \\
$0.1-24.9$ & $1(0.4)$ & $4(0.7)$ & $3(1.3)$ & $2(1.6)$ & $10(0.8)$ \\
0 (no change) & $7(2.6)$ & $1(0.2)$ & $3(1.3)$ & $6(4.8)$ & $17(1.4)$ \\
Worsen & $2(0.7)$ & - & - & $1(0.8)$ & $3(0.3)$ \\
\hline
\end{tabular}

Table 7. Evaluation of total symptom score by patients (in 1181 patients with TSS $=0-12$ )

\begin{tabular}{lccccc}
\hline & Acute Sinusitis & AECB & CAP & Miscell. & Overall \\
\hline No. of patients & 270 & 554 & 232 & 125 & 1181 \\
TSS on day-1 & 3.77 & 7.01 & 8.32 & 6.1 & 6.43 \\
TSS on day-3 & 1.34 & 2.93 & 3.92 & 2.98 & 2.76 \\
TSS on last day & 0.42 & 1.05 & 1.27 & 1.2 & 0.96 \\
\hline
\end{tabular}

Table 8 . The time interval until cure (evaluated by patients in total 1714 patients)

\begin{tabular}{lrrrrr}
\hline \multicolumn{1}{c}{ Day } & $\begin{array}{c}\text { Acute } \\
\text { Sinusitis } \\
\text { n }(\%)\end{array}$ & \multicolumn{1}{c}{$\begin{array}{c}\text { AECB } \\
\mathrm{n}(\%)\end{array}$} & \multicolumn{1}{c}{$\begin{array}{c}\text { CAP } \\
\mathrm{n}(\%)\end{array}$} & \multicolumn{1}{c}{$\begin{array}{c}\text { Miscell. } \\
\mathrm{n}(\%)\end{array}$} & \multicolumn{1}{c}{$\begin{array}{c}\text { All } \\
\mathrm{n}(\%)\end{array}$} \\
\hline $1-3$ & $31(7.9)$ & $60(7.8)$ & $14(4.1)$ & $19(9.3)$ & $124(7.2)$ \\
$4-7$ & $325(82.5)$ & $623(80.8)$ & $243(70.6)$ & $155(75.6)$ & $1346(78.5)$ \\
$8-10$ & $29(7.4)$ & $66(8.6)$ & $73(21.2)$ & $15(7.3)$ & $183(10.7)$ \\
$>10$ & $1(0.3)$ & $3(0.4)$ & $4(1.2)$ & $3(1.5)$ & $11(0.6)$ \\
Unspecified & $8(2.0)$ & $19(2.5)$ & $10(2.9)$ & $13(6.3)$ & $50(2.9)$ \\
\hline Total & $394(100.0)$ & $771(100.0)$ & $344(100.0)$ & $205(100.0)$ & $1714(100.0)$ \\
\hline
\end{tabular}

Table 9. Patient impression

\begin{tabular}{|c|c|c|c|c|c|}
\hline & $\begin{array}{l}\text { Acute Sinusitis } \\
\mathrm{n}(\%)\end{array}$ & $\begin{array}{l}\mathrm{AECB} \\
\mathrm{n}(\%)\end{array}$ & $\begin{array}{l}\text { CAP } \\
\mathrm{n}(\%)\end{array}$ & $\begin{array}{c}\text { Miscell. } \\
\mathrm{n}(\%)\end{array}$ & $\begin{array}{c}\text { All } \\
\mathrm{n}(\%)\end{array}$ \\
\hline Good & $386(98.0)$ & 757 (98.2) & $336(97.7)$ & 194 (94.6) & $1673(97.6)$ \\
\hline Not good & $8(2.0)$ & $14(1.8)$ & $8(2.3)$ & $11(5.4)$ & $41(2.4)$ \\
\hline Total & $394(100.0)$ & $771(100.0)$ & $344(100.0)$ & $205(100.0)$ & $1714(100.0)$ \\
\hline
\end{tabular}


a. acute sinusitis

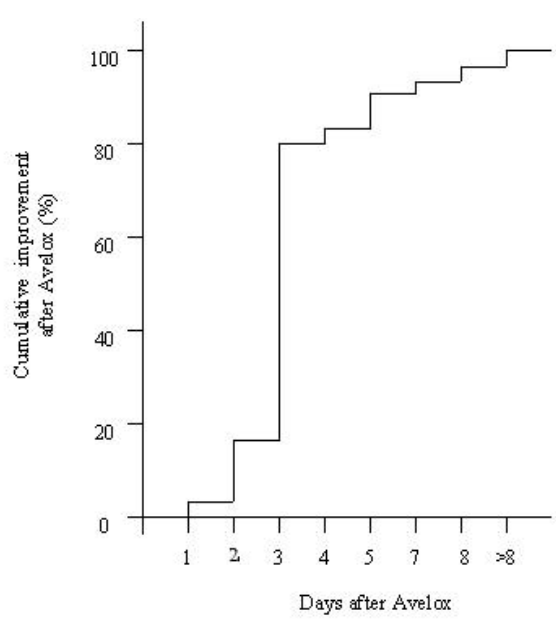

c. community acquired pneumonia

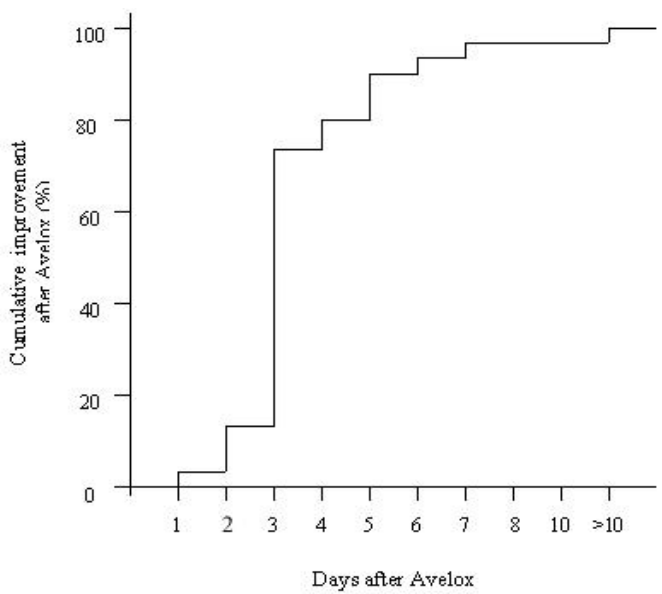

b. acute exacerbation of chronic bronchitis

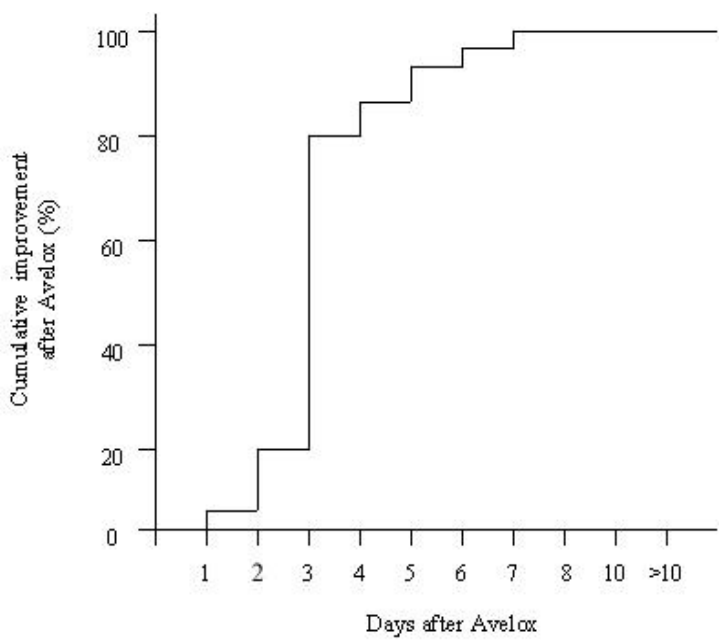

d. miscellaneous diseases

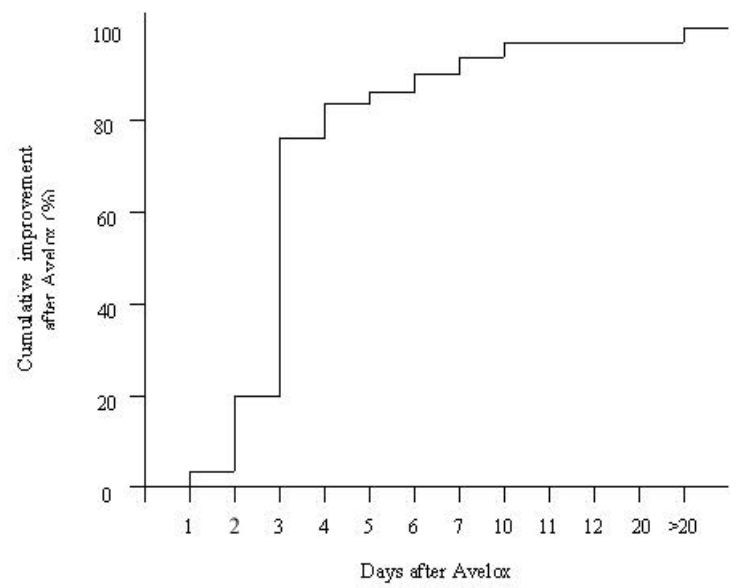

Figure 2. Kaplan-Meier curves for improvement of each diagnosis after moxiflocacin treatment

\section{DISCUSSION}

Moxifloxacin (1-cyclopropyl-7-(2,8-diazobicyclo [4.3.0] nonane)-6-fluoro-8-methoxy-1,4-dihydro-4-oxo-3quinolone carboxylic acid) is a new 8-methoxyquinolone that belongs to the third-generation fluoroquinolones. It has enhanced in vitro activity against Gram-positive bacteria and maintenance of activity against Gramnegative organisms. It is active against common, less common, and atypical respiratory pathogens (Мycoplasma, Chlamydia, and Legionella). This broadrange activity suggests that moxifloxacin may be a suitable antibiotic for the treatment of RTIs, including bronchitis, pneumonia and sinusitis. ${ }^{3}$

Previous monitoring studies showed that gastrointestinal problems were the most common adverse events following fluoroquinolone treatment, particularly nausea, vomiting, and diarrhoea. In patients receiving moxifloxacin $400 \mathrm{mg} /$ day, nausea was observed in $7.8 \%$ patients, although the consequent treatment withdrawal was only $0.85 \%{ }^{4}$ A post-marketing surveillance study in Germany found that the most common adverse event was diarrhoea, which occurred 
in $1.3 \%$ patients. ${ }^{5}$ In the present post-marketing study, gastrointestinal events considered related to moxifloxacin treatment, both serious and nonserious, were accounted for $8 \%$ of all patients. However, most events occurred at a very low rate (less than $1 \%$ ), with the exception of nausea, which occurred in almost 5\% of patients (Tables 2 and 3).Treatment discontinuation due to nausea occurred in 7 patients $(0.41 \%)$ (Table 4$)$.

Following nausea, dizziness was the second most common adverse reaction $(1.52 \%)$ found in this postmarketing study. CNS side effects (dizziness, headache, insomnia, etc.) have been known to occur at a low rate $(2-4 \%)$ in newer fluoroquinolones such as gatifloxacin, gemifloxacin, and moxifloxacin. Serious CNS effect like seizure is very rare; substitution of 7piperazinyl- or 7-pyrrolidinyl-containing compounds in these agents is associated with reduced seizurecausing potential. ${ }^{6}$

Many post-marketing studies gave attention to hepatic and cardiac events. Hepatitis, hepatic failure and cholestatic syndromes have been observed with second-generation fluoroquinolones. ${ }^{4}$ Gatifloxacin, gemifloxacin, and moxifloxacin have not been associated with serious hepatotoxicity reported to occur with trovafloxacin. Mild elevation of transaminase levels (up to 3 times the upper limit of normal) may be found in up to $1 \%$ of patients receiving these agents. ${ }^{6}$ Our current study only found one case of liver dysfunction, however, liver function test was not performed in this post-marketing study.

Cardiotoxicity is another area of concern in using fluoroquinolones. The prolongation of rate-corrected electrocardiographic QT interval (QTc) and the possible development of fatal ventricular arrhythmias (torsades de pointes) is a class effect of fluoroquinolones. ${ }^{6}$ Ciprofloxacin was associated with a significantly lower rate of torsades de pointes. In patients with a risk factor for QT prolongation, levofloxacin should be used with caution, while gatifloxacin use should be avoided. Three cases of torsades de pointes has been reported with the use of moxifloxacin. ${ }^{7}$ A post-marketing surveillance study in Germany found 8 patients experiencing 10 cardiac events, but only one (transient hypotension) was judged to be treatment-related. ${ }^{5}$ Electrocardiographic assessment was not performed in our post-marketing study. Eleven (0.64\%) from 15 cardiac events was judged to be treatment-related, among which, palpitation was the most frequent effect ( 7 cases). One death due to acute heart failure was judged not to be treatment-related.
In 4 patients with SAEs, i.e. 1 patient with bad nausea, 2 patients with nausea \& vomiting, and 1 patient with vertigo, moxifloxacin therapy was not changed and no treatment was given for the SAEs, and the outcomes were either improved (bad nausea) or disappeared completely after 1 day (nausea \& vomiting) or 2 days (vertigo). In 1 patient with liver dysfunction and high fever, moxifloxacin was discontinued and both conditions improved. In these 5 patients, the AEs were considered serious by the attending physicians.

The number of cured and improved patients judged by physicians was very high (97.6\%) in this study. It was very much similar to the number of patients who felt better and who had good impression (Table 8). Numerous randomised comparative clinical studies of moxifloxacin have also reported a clinical success rates of more than $95 \%$ in patients with AECB as well as CAP, which were equivalent or superior when compared directly with another fluoroquinolone or macrolide. ${ }^{8}$

Because of the different respiratory tract infections included in this study, the duration of treatment also varied with the majority of patients received treatment between 4-7 days and the shortest treatment was given to acute sinusitis patients. Treatment for longer than 7 days was mainly observed in more severe cases such as CAP. This result was comparable to a similar study conducted in Germany in patients with CAP, which observed recovery in a mean of 8.6 days. In that study, the majority of patients $(78 \%)$ received therapy between 5 and 10 days $^{5}$. In another study with AECB, recovery occurred in a mean of 6.2 days, and the majority of patients $(75.7 \%)$ recovered by 7 days. ${ }^{8}$

Rapid improvement was consistently seen with moxifloxacin therapy. In the present study, a significant reduction in total symptom score was already observed on the third day of treatment (Table 7), and the majority of patients improved after 3 days treatment (Figure 2). In the above-mentioned studies conducted in Germany, $75 \%$ of AECB patients experienced an improvement within 3 days of treatment and $94.9 \%$ of patients within 5 days. ${ }^{8}$ In the CAP study, over $60 \%$ of patients had clinical improvement after 3 days and almost $90 \%$ were improved by day $5 .^{5}$

Rapid improvement has also been reported in other studies with respiratory tract infections, notably AECB, CAP and acute bacterial sinusitis, in which most patients improved after 3 days. Approximately 
90\% of hospitalised CAP patients improved by day- 5 following moxifloxacin therapy. Similar results were also found in the primary-care setting. These findings were in accordance with the high eradication rate (up to $97 \%$ ) of moxifloxacin treatment for all common respiratory tract pathogens. ${ }^{8}$

\section{CONCLUSIONS}

The results of this PMS study in over 1700 patients with respiratory tract infections, mainly acute sinusitis, acute exacerbation of chronic bronchitis, and community-acquired pneumonia, has demonstrated that treatment with moxifloxacin $400 \mathrm{mg}$ once daily was safe and well tolerated. Moxifloxacin was also shown to be highly effective in the treatment of these infections with rapid improvement of symptoms.

\section{Acknowledgment}

We acknowledged PT Bayer Indonesia for funding this study. We also thanked all physicians who participated in this post-marketing study.

\section{REFERENCES}

1. Lode H. Current approaches to optimising treatment for respiratory tract infections [Editorial]. Clin Drug Invest 2001;21(12):797-9.

2. Blondeau JM, Felmingham D. In vitro and in vivo activity of moxifloxacin against community respiratory tract pathogens. Clin Drug Invest 1999;18(1):57-78.

3. Wise R. A review of the clinical pharmacology of moxifloxacin, a new 8-methoxyquinolone, and its potential relation to therapeutic efficacy. Clin Drug Invest 1999; 17(5):365-87.

4. Ball P, Mandell L, Niki Y, Tillotson G. Comparative tolerability of the newer fluoroquinolone antibacterials. Drug Safety 1999;21(5):407-21.

5. Landen H, Bauer T. Efficacy, onset of action and tolerability of moxifloxacin in patients with communityacquired pneumonia. Results of a post-marketing surveillance study. Clin Drug Invest 2001;21(12):801-11.

6. Saravolatz LD, Leggett J. Gatifloxacin, gemifloxacin, and moxifloxacin: the role of 3 newer fluroquinolones. Clin Infect Dis 2003;37:1210-5.

7. Frothingham R. Rates of torsades de pointes associated with ciprofloxacin, ofloxacin, levofloxacin, gatifloxacin, and moxifloxacin. Pharmacother 2001;21(12):1268-72.

8. Bauer T, Landen H. Rapid resolution of symptoms with moxifloxacin therapy in 7223 patients with acute exacerbation of chronic bronchitis. Comparison with prior macrolide therapy. Clin Drug Invest 2002;22(10):641-51. 